\title{
Students' Review on Interpreting Teaching in Libya: Challenges and Future Prospects
}

\author{
Mohammed Juma Zagood \\ College of Humanities and Social Sciences, UAE University \\ $\mathrm{Al}$ Ain, UAE
}

\begin{abstract}
This empirical study discusses the challenges faced by interpreting students at the Department of Translation and Interpreting Studies at the Libyan Academy in Tripoli. It attempts to answer the following question: what is the students' perspective on the teaching of interpreting at the Libyan Academy? To answer the aforementioned question, a questionnaire has been designed for the aim of identifying the challenges encountered by students of interpreting courses at the Libyan Academy. The questionnaire that consists of closed statements and open questions was given to twelve students who passed the interpreting courses. The questionnaire is designed to include questions about the course structure; materials; the division between theory, methodology and practice; and speeches and audios interpreted. The open questions allowed students to express their views regarding the challenges they faced and the possible future improvements. The findings showed that there are some challenges of interpreting teaching from the students' perspectives. These challenges include the way the courses are divided between theory, methodology, and practice; speeches selected for consecutive interpreting practice, recordings selected for simultaneous interpreting practice, shortage of time slots given to students for practice, out-date lab equipment, and lack of real-life situations where students can practice liaison interpreting. At its conclusion, the significance of this study relies in the suggestion of some recommendations to overcome the challenges raised with the aim of improving interpreting teaching at the Libyan Academy in the future.

Keywords: challenges, interpreting teaching, Libyan students, practice, quality assessment
\end{abstract}

Cite as: Zagood, M. J. (2020). Students' Review on Interpreting Teaching in Libya: Challenges and Future Prospects. Arab World English Journal for Translation \& Literary Studies 4 (4) 3-16. DOI: http://dx.doi.org/10.24093/awejtls/vol4no4.1 


\section{Introduction}

Interpreting is a mediate oral translation of oral discourse (Jones, 1998). It is old and interpreters have played a vital role in communication among nations throughout history. Conference interpreting was born during World War I and then became wider not only in conferences but also in radio and TV programs. Interpreting is of different modes and types: consecutive, simultaneous, liaison, and whispered. In Libya, interpreting was practiced in official meetings and conferences and interpreters were bilinguals from Libya and some other countries though they had no interpreting training in academic and/or training institutions. This is due to the unavailability of training programs till the year 2000 where the Translation and Interpreting Department at the Libyan Academy was established. In this department, interpreting is taught as two courses to master degree students. One course is named Interpreting I in which students study interpreting theory and methodology and practice interpreting from English into Arabic. The other one is Interpreting II, in which students study interpreting theory and methodology and practice interpreting from Arabic into English. The main course book taught is Conference Interpreting Explained by Rodrick Jones (1998) in addition to other articles/essays from other sources. Moreover, most of the time is given to students to practice the four modes of interpreting. These two courses are often taught by the same lecturer. This paper is limited to recap and evaluate the teaching process of both courses: Interpreting I (English-Arabic Interpreting) and Interpreting II (Arabic-English Interpreting). Therefore, the rationale for conducting this study is to evaluate the course structure, materials taught, speeches interpreted and time spent during the teaching of these courses from students' perspectives for the sake of improving them in future. This evaluation is done via a questionnaire which consists of a number of items followed by three open questions given to the students who attended the courses. The answers are analyzed to recognize the challenges and difficulties encountered and to suggest solutions for the sake of improving the teaching process of interpreting in the future. It is hypothesized that students encounter some difficulties in interpreting learning due to a number of factors including the insufficiency of time devoted to practice interpreting. Thus, the research question dealt with in this study is how did students find the teaching structure and materials used in the two interpreting courses and what are the challenges they faced and the possible remedies for future improvement? Therefore, the significance of this study is the expectation that its findings will help future trainers/teachers to utilize the students' feedback for the sake of more effective teaching in the future. This paper takes the form of a case study that provides accurate and reliable results focusing on the teaching of the interpreting courses at the translation and interpreting department at the Libyan Academy in Tripoli. The reliance on students' feedback in improving course materials and teaching comes from the belief that students' evaluation is an influential factor in the development of the teaching process/methods and course materials in any teaching program. Linse (2017) argues that "student ratings are nearly ubiquitous in U.S. higher education and the practice has become more common in other countries in the last few decades" (p. 94).

Studies on assessing teaching programs have always been undertaken and shown useful results that participated in improving those programs. A similar study entitled "what interpreting teachers can learn from students: a case study' has been conducted by Takeda (2010) in which he examines the interpreting teaching program at the Monterey Institute of International Studies (MIIS). The study "serves as a preliminary inquiry into the constructive use of student feedback 
in interpreter education" (Takeda, 2010, p. 12). The findings of the study revealed some issues regarding the students' learning experience, "including interpreting strategies, directionality, language competency, and authenticity", (Takeda, 2010, p. 14). However, the study does not show the students' perspectives regarding the course structure and materials taught at the translation and interpreting program at the MIIS, which represents a gap to be filled. The current study, therefore, is an attempt to fulfill such a gap but in the Libyan context.

As far as the Libyan context is concerned, only one descriptive study on interpreting is found. The study, conducted by Giaber (2010), who describes the conference interpreting situation in Libya after Lockerbie from a professional perspective. Through interviewing some interpreting practitioners, Giaber (2010) found out that conference interpreting practice has flourished in Libya after Lockerbie (air crash on the village of Lockerbie in Scotland in 1989). However, the study does not include findings on interpreting teaching and/or training programs, which again represents a gap that the current study attempts to cover. Accordingly, the current study is the first of its kind that deals with assessing interpreting teaching courses in Libya.

\section{Literature Review}

\section{Interpreting Definition and Modes}

Interpreting has generally been defined as the oral translation of spoken messages. According to Pochhacker (2004), "Interpreting is a form of translation in which a first and a final rendition in another language is produced in a basis of one-time presentation of an utterance in a source language" (p. 11). It is, therefore, the act of facilitating spoken language communication between two or more parties who do not share a common language by delivering, as faithfully as possible, the original message from the source into the target language. "In its distant origins, interpreting took place when (members of) different linguistic and cultural communities entered into contact for some particular purpose" (Pochhacker, 2004, p. 13). An Interpreter is a person who facilitates spoken language communication between two or more parties who do not share a common language by delivering, as faithfully as possible, the original message from the source into the target language (Jones, 1998). Comparing it to translation, interpreting is more difficult as translators deal with written language and have time to polish their work, while interpreters deal with oral language and have no time to refine their output (Gile cited in Baker, 2001, p. 40). Additionally,

In writing we usually have time to plan our message, to think about it carefully and to revise it afterwards if necessary. In speech (unless it is us, say, a lecture prepared in advance) we have no time for this, but must shape our message as we go... In speech we often use words and phrases like well, you see, and kind of which add little information but tell us something of the speaker's attitude to his audience and to what he is saying. We also often hesitate or fill in gaps with hesitation fillers like er and um while we think of what next to say. We may fail to complete a sentence and mix up one grammatical construction with another. All these features do not normally occur in writing. (Harris quoted in Petrscu 2013, p. 3270)

Arab World English Journal for Translation \& Literary Studies 
Interpreting is of various modes and can be practiced in different situations. The common types are Consecutive Interpreting, Simultaneous Interpreting, Liaison (Community) Interpreting, and Whispered Interpreting. The following is a summary of these types:

\section{Consecutive Interpreting}

It is the interpreting of speech part by part. In Consecutive Interpreting, the interpreter listens to a speech segment for a few minutes or so, takes notes and then delivers the whole segment in the target language. Then, the speaker resumes for a few minutes, the interpreter delivers the next segment and the process continues till the end of the speech (Jones, 1998). The essential part of a consecutive interpreter's work is done in the note-taking skill. Notes are mainly taken to relieve memory, jog the interpreter's memory, and to enhance the interpreter's ability to reproduce the structure of a speech. The interpreter should also be careful with what to note, how to note, when to note, and how to read back notes. Interpreters usually use short forms, symbols, abbreviations, etc. to take notes easily and quickly.

\section{Simultaneous Interpreting}

It is the simultaneous (or immediate) rendering of speech. Simultaneous Interpreting is the nearly instantaneous delivery of the speaker's message from the SL to the TL. The interpreter sits in a special room called booth, listens to the speaker through headphones and, at the same time, transfers orally the speaker's speech into a microphone. The microphone carries the interpreting to the audience through headsets. Delegates in the conference room listening to the target language version through headsets attached to their seats (Jones, 1998). The simultaneous interpreter has to be careful with when to start interpreting, how to catch up with the speaker, and how to deal with mistakes.

\section{Liaison/Community Interpreting}

Community interpreting is bidirectional interpreting that takes place in the course of communication among speakers of different languages. Community interpreting "covers both interpreting in face-to-face situations and interpreting provided over the telephone and is probably the most common type of interpreting in the world" (Wadensjo, 1999, p. 251). The context is the provision of public services such as healthcare or community services to facilitate the communication process between monolingual communicators and in settings such as government agencies, community centers, legal settings, educational institutions, immigration departments, and social services (Wadensjo, 2001). Other terms have also been used to describe community interpreting such as 'public service interpreting', 'cultural interpreting', 'dialogue interpreting', 'institutional interpreting', 'liaison interpreting', and 'ad hoc interpreting'.

\section{Whispered Interpreting}

Whispered interpreting is the one that takes place whereby the interpreter is seated next to one or more of the delegates and whispers in the target language the content of the speech.

Whispered Interpreting (or Chuchotage) is a form of simultaneous interpreting in which the interpreter does not sit in a booth but in the conference room, next to the delegate 
who needs the interpreting, and whispers the target-language version of the speech in the delegate's ears (Gile as quoted in Baker, 2001, p. 42).

\section{A Background on Translation and Interpreting Teaching in Libya}

Studies on reviewing interpreting teaching programs has recently attracted the attention of researchers and teachers of interpreting for the sake of improving the quality of their graduates. A recent study on the acquisition of interpreting strategies by student interpreters has been conducted by Dong et al, (2019). Throughout this study, they explored the acquisition of interpreting strategies adopted by 66 student interpreters in consecutive interpreting. Using quantitative and qualitative approaches for data analysis, Dong et al, found out that "strategy training is effective, and strategy acquisition is plausible" (p. 1). This study is, therefore, an attempt to review the teaching of interpreting courses from students' perspective.

Translation was taught in Libya as one or more modules within foreign language departments until the end of the last decade of the twentieth century where the need for academically and professionally trained translators and interpreters has emerged due to the following reasons:

1. The suspension in 1999 of the UN sanctions imposed on Libya in 1992 after the Lockerbie case (air crash on the village of Lockerbie in Scotland in 1989).

2. The shift in the Libyan political orientation from Arab nationalism to Africanism.

3. The increase of the foreign investment in Libya.

4. The shift from socialism to capitalism and the encouragement of private business and partnership with foreign capitalists and investors (cf. Giaber, 2005, p. 5).

In addition, translation and interpreting services were also needed to aid refugees, immigrants, and other crisis situations by both governmental and non-governmental organizations (NGOs). However, there is "little understanding ... of translation and interpreting policies and practices in (international) NGOs, and a lock of in-depth case studies on how specific NGOs may deal with their language needs" (Tesseur, 2018, p. 4). Accordingly, the demand for translators and interpreters remains high especially for the emerging markets, (Cabrera, 2017).

The Libyan context is no exception due to the fact that "the institutional training of translators and interpreters is a relatively new phenomenon" (Caminade \& Pym, as cited in Baker, 2001, p. 280). Therefore, an urgent demand for qualified and competent translators and interpreters emerged and education institutions started to establish departments and training centers for translation and interpreting to meet such demands. The Translation and Interpreting Studies program at the Libyan Academy "was established during the second half of the year 2000" (Giaber, 2005, p. 12) as a response to the demand for translators and interpreters. Other undergraduate programs and training centers were also established at other universities. However, the program at the Libyan Academy is still the only postgraduate academic one in which translation and interpreting are taught. "The aim of the program was to produce qualified translators/interpreters (English-Arabic/ Arabic-English) and translation specialists", (Giaber, 2005, p. 5). Only a few years after its establishment, the program became well known nation-wide and gained a good Arab World English Journal for Translation \& Literary Studies

ISSN: 2550-1542 | www.awej-tls.org 
reputation at local and regional levels. Many students were enrolled after passing admission tests that were designed in both languages (English and Arabic) and tests both translation and interpreting skills. Once admitted, the student should pass ten modules, prepare a dissertation proposal and discuss it before a panel for approval. After the approval of a student's proposal, the department assigns them a supervisor and they have to submit and defend their dissertation within a year. In case a student failed to submit a well-written dissertation within a year, they are warned and given six months to do so; otherwise, they are only given a postgraduate diploma in translation and interpreting not an MA. However, it is useless as it is not considered a degree, according to the Libyan Education Law.

The department has flourished and attracted many well-qualified faculties and lecturers from Libya and some other countries to teach, supervise, and examine students. Following this success, and only five years after its establishment, the department started organizing an annual international conference on translation where many academic papers presented by students, graduates, faculties, and national and international specialists including key figures in the field who were invited as keynote speakers. The conference was organized for six consecutive years from 2005 to 2010. Starting from 2011, the translation and interpreting program witnessed some drawbacks due to what so-called 'Arab-Spring'. The annual translation conference suspended due to security and financial issues. Many non-Libyan faculties left the country and some Libyans also left to work abroad, which caused a shortage of faculties. For such reasons, many students faced problems in studying and finding supervisors for their dissertations and consequently decreases the number of student enrollment in the department. However, there is still some ray of hope and the program is still graduating a few numbers of students every year.

The translation and interpreting program at the Libyan Academy consists of ten modules and a dissertation. Students are required to take the ten modules before they start writing their dissertations. The ten courses are Introduction to Translation Studies, General Linguistics, Translation Methodology, Research Methodology, Translating Political and Diplomatic Texts, Translating Business and Administrative Texts, Translating Legal and Technical Texts, Translating Journalistic and Literary Texts, Interpreting I (English-Arabic Interpreting), and Interpreting II (Arabic-English Interpreting). Accordingly, interpreting is taught in two courses: English-Arabic Interpreting and Arabic-English Interpreting. Arabic is the official language of the country and the mother tongue of the vast majority of the population. English is the world lingua franca and almost always available in the Libyan market. Therefore, these two languages are the ones taught in the aforementioned program. In the two interpreting modules, interpreting theory and methodology are taught and different modes of interpreting are practiced. It is, therefore, a prerequisite that students pass all translation theory, methodology, and translation practice modules before taking the interpreting courses. Conference Interpreting Explained by Jones (1998) is the main textbook used in addition to some articles taken from different books. The semester at the Libyan Academy consists of 14 weeks and, accordingly, the materials taught in the two courses taught divided per week are shown in appendix one.

In the theoretical part of those courses, students are taught a general overview of interpreting and the definitions of interpreting-related terms, the difference between translation 
and interpreting, interpreters' role, ethics and standards of practice, cultural and situational tasks of interpreting, modes of interpreting, and the techniques of each mode (e.g. note-taking in consecutive interpreting; and relay, and use of equipment, etc. in simultaneous interpreting). Students are assessed by two direct assessment methods namely oral exams, and submitting a short-written piece of research.

In the practical part, students are exposed to different types of conversations, speeches, audios, and videos of different accents of the language they interpret from (based on the directionality of the course). They were taught to interpret in different interpreting modes as shown in the table above. Pochhacker (2004) states that "most of the literature on interpreter training falls into three prototypical subdivisions: consecutive interpreting with note-taking; simultaneous interpreting for international conference settings; and dialogue interpreting in the community" (p. 183). Therefore, a special focus is placed on training students some important skills required in professional interpreters such as active listening skills, good memory retention, note taking, professional dealing with speakers and delegates, use of simultaneous interpreting equipment, etc. While practicing, students are assessed in each interpreting session. The course instructor observes and evaluates the students' performance in terms of professionality, skillfulness in note-taking (in consecutive interpreting)/use of technology (in simultaneous interpreting), keeping eye contact with delegates and audience, speed and flow of interpreting, quality of their interpreting accuracy, and language accuracy. For the sake of objectivity and fairness, the instructor designed the following rubric to assess students' performance. This rubric is used in both courses and in all practical interpreting sessions taking into consideration the time slots given to students and the directionality of interpreting. However, when practicing liaison/community interpreting, students practice interpreting in both directions irrespective of the directionality of the course (EnglishArabic or Arabic-English).

Table 1: Assessment rubric used in assessing students' performance in interpreting

\begin{tabular}{|c|c|c|c|c|c|c|c|}
\hline \multicolumn{2}{|c|}{ Students' Performance Assessment } \\
\hline $\begin{array}{c}\text { Assessment } \\
\text { Criteria }\end{array}$ & Professionalism & $\begin{array}{c}\text { Note-taking } \\
\text { (consecutive)/us } \\
\text { e of equipment } \\
\text { (simultaneous) }\end{array}$ & $\begin{array}{c}\text { Eye } \\
\text { Contact }\end{array}$ & $\begin{array}{c}\text { Speed } \\
\text { and } \\
\text { Flow }\end{array}$ & $\begin{array}{c}\text { Language } \\
\text { Accuracy }\end{array}$ & $\begin{array}{c}\text { Interpreting } \\
\text { Accuracy }\end{array}$ & Total \\
\hline $\begin{array}{c}\text { Assigned } \\
\text { Mark }\end{array}$ & $10 \%$ & $10 \%$ & $10 \%$ & $10 \%$ & $20 \%$ & $40 \%$ & $100 \%$ \\
\hline Gained Mark & & & & & & & \\
\hline
\end{tabular}

Table 2: Interpretation of assessment criteria

\begin{tabular}{|c|l|}
\hline $\begin{array}{c}\text { Assessment } \\
\text { Criterion }\end{array}$ & \multicolumn{1}{c|}{ Its Interpretation } \\
\hline Professionalism & $\begin{array}{l}\text { The student is assessed based on their professional behavior as an interpreter, i.e. how they } \\
\text { stand/sit beside the delegates and before the audience, how they ask for clarification, how they } \\
\text { do not interfere in the conversation/speech, etc. }\end{array}$ \\
\hline Note-taking & $\begin{array}{l}\text { The student is assessed based on what to note, how to note, and whether the notes taken helped } \\
\text { in memory retrieval. }\end{array}$ \\
\hline $\begin{array}{c}\text { Use of } \\
\text { Equipment }\end{array}$ & $\begin{array}{l}\text { The student is assessed based on their ability on using the booth technology, e.g. headset, } \\
\text { microphone and switching with other interpreters. }\end{array}$ \\
\hline \hline
\end{tabular}

Arab World English Journal for Translation \& Literary Studies

ISSN: 2550-1542 | www.awej-tls.org 


\begin{tabular}{|c|l|}
\hline Eye Contact & $\begin{array}{l}\text { The student is assessed based on the eye contact with the speaker while speaking and the } \\
\text { listener/audience while delivering the speech segment. }\end{array}$ \\
\hline $\begin{array}{c}\text { Speed and } \\
\text { Flow }\end{array}$ & $\begin{array}{l}\text { The student is assessed based on their interpreting speed just after the speaker finishes the } \\
\text { speech segment with no stutters, repetition, and/or hesitation. }\end{array}$ \\
\hline $\begin{array}{c}\text { Language } \\
\text { Accuracy }\end{array}$ & $\begin{array}{l}\text { The student is assessed based on their use of grammatically correct language, clear voice, and } \\
\text { correct pronunciation in both languages. }\end{array}$ \\
\hline $\begin{array}{c}\text { Interpreting } \\
\text { Accuracy }\end{array}$ & $\begin{array}{l}\text { The student is assessed based on the accuracy of meaning and message as intended by the } \\
\text { speaker with no additions and/or omissions to the meaning. }\end{array}$ \\
\hline
\end{tabular}

Accordingly, students who pass these two modules are expected to have sufficient knowledge about interpreting and also expected to be able to start working as interpreters. The texts, audios, and videos used in practicing interpreting were almost up to date and included different themes and subjects.

\section{Research Methodology}

According to Yin (1984), "a research design is the logic that links the data to be collected (and the conclusions to be drawn) to the initial questions of a study"(p. 27). Accordingly; just after the completion of Fall Semester last year, students who passed the two interpreting courses (English-Arabic and Arabic-English) were given a questionnaire to express their views on the teaching of the two interpreting courses and provide suggestions for improving them in future.

\section{Participants}

The students who took the two modules were 15 students, but only 12 (80\%) of them participated in this study. The participants were only those who passed the two interpreting courses. By completing these two courses, the students are given a postgraduate diploma in translation and interpreting studies and are allowed to embark upon writing their MA dissertations. The participants were males and females and their ages range between 25 and 35 years. They had no experience in interpreting before taking these two courses but, of course, had some experience in translation as they passed some translation practice courses and submitted some translation portfolios.

\section{Instruments}

A questionnaire is used as main data collection tool in an attempt to find answers to the research question mentioned earlier. The questionnaire consists of two parts (closed questions and open ones). Part one (the closed questions) comprises twelve statements and students had to respond to each statement with agree, undecided, or disagree. The statements used in the questionnaire along with samples of students' answers are shown in the data analysis section below. Part two (the open questions) includes three questions through which the participants were given the freedom and space to answer. The three questions along with samples of the students' answers are shown in the data analysis section below. After designing the questionnaire and before the actual administration, it was piloted by being answered by a few numbers of senior students who had passed the courses in previous semesters. The reason was to pre-assess the questionnaire (1) to make sure the questions are unambiguous and elicit the needed data to answer the research questions stated earlier; (2) to identify any possible issues that may affect the final administration of the questionnaire; and (3) to decide on the approximate time that the participants need to answer 
the questionnaire. The questionnaire was, then, revised according to the pilot study results and structured in clear and simple English and in a pleasant layout so that it is read easily. For the sake of confidentiality and privacy and to avoid any embarrassment and/or hesitation in answering the questionnaire, students were told about the purpose of this questionnaire and were asked not to write their names on the answer sheets. Accordingly, they were told that the results of the questionnaire would only be used to collect their views on the teaching materials and approach for two purposes: research and improvement of interpreting teaching in future. They expressed their willingness and answered the questionnaire with pleasure.

\section{Data Analysis}

The quantitative approach is adopted in analyzing the closed questions used in the questionnaire. The analysis is basically made in a form of a table. Table Four below shows the results obtained, i.e. the answers of each statement are numerated to find out the percentages of agree, undecided, and disagree.

Table 3. The quantitative data analysis

\begin{tabular}{|c|c|c|c|c|c|c|c|}
\hline \multirow[t]{2}{*}{ No. } & \multirow[t]{2}{*}{ Statement } & \multicolumn{2}{|c|}{ Agree } & \multicolumn{2}{|c|}{ Undecided } & \multicolumn{2}{|c|}{ Disagree } \\
\hline & & No. & $\%$ & No. & $\%$ & No. & $\%$ \\
\hline 1 & $\begin{array}{l}\text { The course book and articles chosen for these courses were } \\
\text { useful }\end{array}$ & 12 & 100 & 0 & 0 & 0 & 0 \\
\hline 2 & $\begin{array}{l}\text { Discussing the book and articles in the time allotted for the } \\
\text { theoretical part was sufficient }\end{array}$ & 6 & 50 & 4 & 33 & 2 & 17 \\
\hline 3 & $\begin{array}{l}\text { Dividing the course between theory, methodology, and practice } \\
\text { was appropriate and useful }\end{array}$ & 8 & 67 & 4 & 33 & 0 & 0 \\
\hline 4 & $\begin{array}{l}\text { The time (six lectures }=18 \text { hours) given to consecutive } \\
\text { interpreting practice was enough }\end{array}$ & 8 & 67 & 2 & 17 & 2 & 17 \\
\hline 5 & $\begin{array}{l}\text { The time (four lectures }=12 \text { hours) given to liaison interpreting } \\
\text { practice was enough }\end{array}$ & 10 & 83 & 2 & 17 & 0 & 0 \\
\hline 6 & $\begin{array}{l}\text { The time (two lecture }=6 \text { hours) given to whispered } \\
\text { interpreting practice was enough }\end{array}$ & 8 & 67 & 2 & 17 & 2 & 17 \\
\hline 7 & $\begin{array}{l}\text { The time (six lectures }=18 \text { hours) given to simultaneous } \\
\text { interpreting practice was enough }\end{array}$ & 8 & 67 & 0 & 0 & 4 & 33 \\
\hline 8 & $\begin{array}{l}\text { The time slots given to each student to practice interpreting was } \\
\text { sufficient and practical, and equal to others. }\end{array}$ & 10 & 83 & 2 & 17 & 0 & 0 \\
\hline 9 & $\begin{array}{l}\text { The written speeches chosen for consecutive interpreting } \\
\text { practice were appropriate }\end{array}$ & 10 & 83 & 2 & 17 & 0 & 0 \\
\hline 10 & $\begin{array}{l}\text { The audio and video recordings chosen for whispered and } \\
\text { simultaneous interpreting practice were appropriate }\end{array}$ & 6 & 50 & 2 & 17 & 4 & 33 \\
\hline 11 & $\begin{array}{l}\text { You found that you learnt much in interpreting theory and } \\
\text { methodology }\end{array}$ & 10 & 83 & 2 & 17 & 0 & 0 \\
\hline 12 & You practiced interpreting and ready to start an interpreting job & 4 & 33 & 4 & 33 & 4 & 33 \\
\hline
\end{tabular}

\section{Interpretation of the Research Findings}

The above table shows the following results:

1. All students $(100 \%)$ were happy with the course structure and teaching materials, i.e. the course book and articles used as reading materials in the course were appropriate.

2. Half of the students $(50 \%)$ found that the time (six weeks/ 18 hours) devoted to the theoretical part was sufficient and beneficial. One third of them $(33 \%)$ have undecided 
regarding the division of the course between theory, and practice. Whereas, $17 \%$ of the students did not appreciate such division as they wanted more time for practice.

3. Two thirds of students (67\%) have also appreciated the division of the course between theory, methodology, and practice. However, a third of them (33\%) have undecided regarding such division. None of them $(0 \%)$ disagreed on dividing the course this way.

4. Two thirds of students (67\%) agreed that the time (three weeks/ nine hours) slots given to them to practice consecutive interpreting was sufficient. $17 \%$ of students have undecided and $17 \%$ of them thought that the time devoted to practicing consecutive interpreting was insufficient.

5. $83 \%$ of students thought that the time slots (three lecture/ nine hours) devoted to practicing liaison interpreting was sufficient and beneficial. Only $17 \%$ of them have undecided and none $(0 \%)$ has disagreed.

6. Two thirds of students (67\%) found that the time slots given to practice whispered interpreting was sufficient. Only $17 \%$ have undecided and $17 \%$ found it insufficient.

7. Two thirds of students (67\%) agreed that the time slots given to practice simultaneous interpreting was enough. None of them undecided and one third of students $(33 \%)$ were unhappy with the time slots given to them to practice simultaneous interpreting.

8. $83 \%$ of students agreed that the time slots given to each student was practical and almost equal to others, which means that the time was divided equally and fairly among students to practice interpreting. Only $17 \%$ of students have undecided regarding the practicality, usefulness and fairness of time division among students. None of them (0\%) expressed their disagreement on this issue.

9. $83 \%$ of students agreed that the written texts/speeches chosen for consecutive interpreting practice were appropriate and useful. Only 17\% have undecided and none of them (0\%) expressed their disagreement on the choice of the texts/speeches used for consecutive interpreting practice.

10. Half of the students $(50 \%)$ were happy with the selection of audio and video recordings used to practice simultaneous interpreting. 17\% have undecided and one third of them (33\%) have disagreed on the selection of such audio and video recordings for practice.

$11.83 \%$ of students agreed that they learnt much about interpreting theory and methodology. Only $17 \%$ of students have undecided and none $(0 \%)$ has mentioned that they did not learn about interpreting theory and methodology.

12. One third of students (33\%) found that they are able to start an interpreting job after the completion of these two courses. One third of students (33\%) have undecided whether they can work as interpreters or not. One third (33\%) thought that they are not yet ready to start interpreting jobs and have expressed their inability to work as interpreters although they passed the two interpreting courses. It seems that they still lack confidence and/or still need more practice.

In their answers to the three open questions used in the questionnaire, it seems that they agreed with their answers to the closed questions shown above. As mentioned earlier, students were given the freedom and space to express their views on the two interpreting courses and suggest amendments for the sake of improving the courses in the future. For the sake of objectivity, three 
samples of students' answers (representing 25\% of the total answers) have been randomly selected and quoted below:

\section{How did you find the course in general?}

Student 1: "Personally, I found it extremely useful; I found that the way the course was divided between practice and theory was intelligent, as no one can do without the other. So in paper, the course was well organized, the problems arose from the fact that the lab was not well equipped and the time was not enough, so we managed with what we had. In short, it was good but it could have been better".

Student 2: "Actually, I learnt a lot from it in the theoretical part, but as for the practical part, I did not find it that much interesting even though the doctor himself did his best to teach us, but I myself aspired for more. The course was good in general".

Student 3: "the theoretical part was very helpful for me and interpreting was a good fun experience. Trying different types of interpreting made me able to know which one can be good for me to work as an interpreter in the future. One more thing, we need more references in interpreting to do well in the theoretical part".

2. Do you think any part of this course needs to be improved in future? Explain. Student 1: "I think the time is not enough. Each student should be given more time to practicing and the lab should be ready and working. The fact it was not ready hindered us a lot. Another point I should shed light on is that students who did not study Interpreting I should not be enrolled in Interpreting II, as they are not familiar with the course".

Student 2: "Yes, I do. It needs more improvement when it comes to the practical section. More practice must be given to students and more role play. More ways of interpreting should be taught, and the students must learn how to feel confident and speak in public. Above all, I have benefitted a lot from this course".

Student 3: "I think that the theoretical part and the practical should be divided into two separate courses in order to have more time for practice".

\section{Any more comments/criticism/suggestions, etc.}

Student 1: "I found the videos, texts we studied very interesting and up to date and of the kind we will face in the future careers. I just think the time slot with the number of students is not enough, the course should not have more than 5 students since it is a practical module". 
Student 2: "No, I'd like to thank Dr. (...) for his great efforts he showed us during the course. I'd also want to wish him nothing but the best of luck in his scientific and practical life. All the best".

Student 3: "There are many students and we did not get enough time for practice. More interpreting practice especially in simultaneous interpreting is needed".

\section{Conclusion}

This paper has described the current situation of interpreting teaching at the Translation and Interpreting Department at Libyan Academy in Tripoli. At this department, interpreting is taught in two courses (English-Arabic and Arabic-English). The courses are designed to include both theory and practice. A questionnaire has been designed to recognize how students perceive the interpreting course and to identify the challenges faced for the sake of improving interpreting teaching in Libya. The findings of this study have shown that there are some good aspects while others need some improvements. The main challenges face the teaching of interpreting can be summarized in the division of the course between theory, methodology, and practice; the choice of speeches for consecutive, and recordings for simultaneous interpreting practice, the number of students enrolled in the courses resulting short time slots given to each student to practice interpreting, and the existence of out-date lab equipment, lack of real situations where students practice liaison interpreting apart from the class. Therefore, the department of translation and interpreting at the Libyan Academy is recommended to:

1. Add one more interpreting course in which interpreting theory is taught. It is to cover the theoretical and methodological aspects of interpreting and the interpreters' ethics and standards of practice. Two practical courses are to be devoted to practice only to give students more time slots to practice different modes of interpreting.

2. Use more up-to-date references to teach interpreting theory and methodology.

3. Decrease the number of students enrolled in interpreting courses to give the enrolled students longer time slots for practice.

4. Provide and install an up-to-date conference interpreting laboratory.

5. Update the course materials especially the speeches and audios to be used as authentic materials for practice.

6. Send students to other institutions in an internship for real-life interpreting situations.

\section{About the Author:}

Mohammed Juma Zagood is an Assistant Prof. of Translation Studies at UAE University. He got his PhD from Durham University in 2012. Currently, he is teaching translation and interpreting courses at the UAEU. Since 2012, Dr. Zagood has participated in a number of international conferences and published some articles in journals and conference proceedings. ORCID ID: https://orcid.org/0000-0002-7786-2667

\section{References}

Baker, M. ed. (2001). Routledge Encyclopedia of Translation Studies. Routledge: London and New York. 
Cabrera, T. (2017). The Translation and Interpreting Industry in the United States. Harvard University: Observatorio.

Caminade, M. \& Pym, A. (2001). 'Translator-Training Institutions. In M. Baker (Ed) Routledge Encyclopedia of Translation Studies. 280-286. London and New York: Routledge.

Dong, Y. Li, Y. \& Zhao, N. (2019). Acquisition of Interpreting Strategies by Student Interpreters. The Interpreter and Translator Trainer.

DOI:10.80/1750399X.2019.1617653.

Giaber, J. (2005). The Increasing Role of Translation in Libyan Politics and Business Activities. In International Journal of Arabic-English Studies (IJAES), 6, 181-188. APETAU.

Giaber, J. M. (2010). Conference Interpreting in Libya after Lockerbie. Faculty of Language's Journal, 5, 27-33. Tripoli: Tripoli University Press.

Gile, D. (2001). Conference and Simultaneous Interpreting. In M. Baker (Ed), Routledge Encyclopedia of Translation Studies (pp. 40-45). London and New York: Routledge.

Gillies, A. (2013). Conference Interpreting. London and New York: Routledge.

Hale, S. (2007). Community Interpreting. New York: Palgrave Macmillan.

Hun, X. (2013). The Skill-Focused Approach to Interpretation Teaching: An Emperical Exploration. The Open Journal of Modern Linguistics, 3, (2), 161-165.

Jones, R. (1998). Conference Interpreting Explained. Manchester: St. Jerome Publishing.

Linse, A. (2017). Interpreting and Using Student Ratings Data: Guidance for Faculty Serving as Administrators and on Evaluation Committees. Studies on Education Evaluation, 54, 94106.

Morin, I. (2007). Six Phases in Teaching Interpretation as a Subject at Universities and Colleges in Indonesia. Translation Journal. Available at URL: http://translationjournal.net/journal/40interpret.htm. (retrieved in 2/8/2020).

Petrescu, C. (2013). Teaching Interpreting. Paper presents at the $5^{\text {th }}$ World Conference on Educational Sciences- WCES2013. Timisoara: University of Timisoara.

Pochhaker, F. (2004). Introducing Interpreting Studies. London and New York: Routledge.

Takeda, K. (2010). What Interpreting Teachers Can Learn from Students: A Case Study. The International Journal for Translation and Interpreting, 2 (1), 38-49 Trans-int.org.

Taylor-Bouladon, V. (2000). Conference Interpreting: Principles and Practice. Goolwa: Crawford House Publishing.

Tesseur, W. (2018). Researching Translation and Interpreting in Non-Governmental Organisations. Translation Spaces. DOI: 10.1075/ts.00001.tes Available at file:///C:/Users/MJMZAG 1/AppData/Local/Temp/1.TES-s.pdf. (retrieved in 2/8/2020)

Wadensjo, C. (1999). Telephone interpreting and the synchronization of talk in social interaction. The Translator, 5(2), 247-264.

Wadensjo, C. (2001). Community Interpreting'. In M. Baker (Ed), Routledge Encyclopedia of Translation Studies (pp. 33-37). London and New York: Routledge.

Yin, K. Robert (1984). Case Study Research: Design and Methods. Applied Social Research Methods Series, 5. London and New Delhi: Sage Publications.

\section{Appendix One}

Weekly classes in both Interpreting I (English-Arabic) and Interpreting II (Arabic-English) \begin{tabular}{l|ll} 
Teaching Week & Topics \\
\hline
\end{tabular}

Arab World English Journal for Translation \& Literary Studies

ISSN: 2550-1542 | www.awej-tls.org 
AWEJ for Translation \& Literary Studies Volume, 4 Number 4. October 2020

\begin{tabular}{|c|c|}
\hline Week 1 & Introduction to the Course. Types and Modes of Interpreting. \\
\hline Week 2 & Consecutive Interpreting: e.g. Note-taking. \\
\hline Week 3 & $\begin{array}{l}\text { Simultaneous Interpreting: e.g. The Techniques of Simultaneous Interpreting. Students are } \\
\text { also asked to start writing their assignments on any interpreting related topic of their choices. }\end{array}$ \\
\hline Week 4 & $\begin{array}{l}\text { Liaison/Community Interpreting Practice. Students are required to interpret in both directions } \\
\text { (English-Arabic-English) dialogues in different settings including government agencies, } \\
\text { community centres, educational institutions, and social services. }\end{array}$ \\
\hline Week 5 & $\begin{array}{l}\text { Liaison/Community Interpreting Practice. Students are required to interpret in both directions } \\
\text { (English-Arabic-English) irrespective of the directionality of the course (i.e. Interpreting I or } \\
\text { Interpreting II) more challenging dialogues in legal and business settings and on controversial } \\
\text { issues. }\end{array}$ \\
\hline Week 6 & $\begin{array}{l}\text { Consecutive Interpreting Practice. Students are trained to understand and analyse the discourse, } \\
\text { and enhance the role of memorization and note-taking. They are required to interpret } \\
\text { extemporaneous speeches from English into Arabic (Interpreting I) and Arabic into English } \\
\text { (Interpreting II) }\end{array}$ \\
\hline Week 7 & $\begin{array}{l}\text { Consecutive Interpreting Practice. Students are required to interpret increasingly long written } \\
\text { challenging speeches on commercial, technical, political topics, etc. from English into Arabic } \\
\text { (Interpreting I) and Arabic into English (Interpreting II). }\end{array}$ \\
\hline Week 8 & $\begin{array}{l}\text { Consecutive Interpreting Practice. Students are required to interpret increasingly long written } \\
\text { challenging speeches on commercial, technical, political topics, etc. from English into Arabic } \\
\text { (Interpreting I) and Arabic into English (Interpreting II). }\end{array}$ \\
\hline Week 9 & $\begin{array}{l}\text { Mid-term Examination. It consists of two sessions: one liaison interpreting, and one English- } \\
\text { Arabic consecutive interpreting (Interpreting I) and Arabic-English consecutive interpreting } \\
\text { (Interpreting II). }\end{array}$ \\
\hline Week 10 & $\begin{array}{l}\text { Whispered Interpreting Practice. Students are required to interpret a written speech in a } \\
\text { whispered mode from English into Arabic (Interpreting I) and Arabic into English } \\
\text { (Interpreting II).to familiarize them how this mode of interpreting is used. }\end{array}$ \\
\hline Week 11 & $\begin{array}{l}\text { Simultaneous Interpreting Practice. Students are required to simultaneously interpret } \\
\text { improvised speeches from English into Arabic (Interpreting I) and Arabic into English } \\
\text { (Interpreting II). }\end{array}$ \\
\hline Week 12 & $\begin{array}{l}\text { Simultaneous Interpreting Practice. Students are required to simultaneously interpret authentic } \\
\text { recorded and well-prepared speeches from English into Arabic (Interpreting I) and Arabic into } \\
\text { English (Interpreting II). The speeches are selected from various sources on different topics } \\
\text { according to difficulty levels. }\end{array}$ \\
\hline Week 13 & $\begin{array}{l}\text { Simultaneous Interpreting Practice. Students are required to simultaneously interpret authentic } \\
\text { recorded and well-prepared speeches from Arabic into English (Interpreting I) and Arabic into } \\
\text { English (Interpreting II). The speeches are selected from various sources on different topics } \\
\text { according to difficulty levels. Students have to submit their assignments before sitting for the } \\
\text { final examination. }\end{array}$ \\
\hline Week 14 & $\begin{array}{l}\text { Final Examination. It consists of two simultaneous interpreting sessions: In the first one, } \\
\text { students are required to interpret improvised speech from English into Arabic (Interpreting I) } \\
\text { and Arabic into English (Interpreting II). In the second session, students are required to } \\
\text { interpret an authentic recorded speech from English into Arabic (Interpreting I) and Arabic } \\
\text { into English (Interpreting II). }\end{array}$ \\
\hline
\end{tabular}

Arab World English Journal for Translation \& Literary Studies 